\title{
STUDIES ON THE EFFECT OF PROBENECID ('BENEMID') IN GOUT
}

\author{
BY \\ R. M. MASON \\ Department of Rheumatic Diseases, West London Hospital
}

(RECEIVED FOR PUBLICATION FEBRUARY 10, 1954)

The discovery by Wollaston (1797) of uric acid in a gouty tophus, and the demonstration by Garrod (1848) that uric acid existed in excess amounts in the blood of gouty subjects, have not been followed as yet by any clear understanding of the precise relationship between this substance and the disease. In particular, the mechanism of production of the acute attack remains unexplained, and there exists a fascinating gap in our knowledge of the link between this striking clinical phenomenon and that relatively simple compound uric acid. Several reasons for this exist. Intervals between attacks may be as long as 62 years (Bauer, 1943), and it is therefore unusual to be able to observe the biochemical changes of an acute attack occurring fortuitously. Artificially induced attacks are unsatisfactory; high purine or high fat diets may themselves affect blood uric acid levels (Brøchner-Mortensen, 1939; Bauer, 1943; Bauer and Klemperer, 1947; Marson, 1953), and, although acute attacks have been observed after the administration and withdrawal of ACTH (Hellman, 1949; Levin and others, 1953), this substance has a uricosuric action (Forsham and others, 1946, 1948; Robinson and others, 1948; Gutman and Yü, 1950; Thorn and others, 1950; Wolfson and others, 1950), which renders interpretation difficult. Furthermore, the complete clinical remissions which characterize gout render the necessary in-patient observation during these periods difficult to achieve, and the tendency is for only those patients who have reached the chronic stage to accept this. Secondly, the classical severity of the acute paroxysm, so graphically referred to in the literature (e.g. by Sydenham, 1683; and, in more recent years, by Wood-Jones, 1948, 1950) renders it impossible to observe an untreated acute attack. Finally, the development of reliable and practical biochemical methods for the quantitative determination of uric acid in body fluids has proved difficult, and this is reflected in the massive literature on this problem. That adequate accuracob can be achieved, however, has been confirmed by thie use of uricase (Blauch and Koch, 1939; Block and Geib, 1947), whereby the inaccuracy produced bo non-uric acid chromogens can be excluded ant measured. Buchanan and others (1945) have est $\vec{E}-$ mated that non-uric acid chromogenic material if the urine amounts to $60-90 \mathrm{mg} . / 24 \mathrm{hrs}$, and Johro stone (1952), using a combination of the coloug reagent of Brown (1945) and the uricase method off Block and Geib, found that they accounted fow $7 \mathrm{mg} . / 100 \mathrm{ml}$. in the urine and $0.2 \mathrm{mg}$. $/ 100 \mathrm{ml}$. in the plasma. There was no correlation between nor uric acid chromogens and uric acid, the former being within normal limits, and the difference betweeg normal and gouty readings being due to uric acic The only significant error from this source occus in the presence of renal failure.

Many workers report that at least a proportion gouty subjects show normal values in the blood varying in different series from 7 to 28 per cen 5 (Cohen, 1936; Hench and others, 1928; Hill, 1938 के An analysis of blood uric acid estimations on eight. gouty subjects, when no drugs had been taken fof 24 hours during periods of freedom from acute paroxysms, has been made on the material of 9 previous study (Mason, 1951), and this reveals thas twelve readings ( 24 per cent.) out of 51 were belo $4 \mathrm{mg}$. per cent. This figure agrees with those quote of the proportion of cases of gout having a normaP level. On the other hand, the relatives of gouts patients are not infrequently found to be sufferin from asymptomatic hyperuricaemia (Talbott and Coombs, 1938a; Talbott, 1940, 1951). It is alsê recognized that hyperuricaemia due to renal failure is not associated with attacks of gout. Furthef? more, the artificial production of gross hypero uricaemia by intravenous administration, even i⿳⺈ gouty subjects, to over $20 \mathrm{mg}$. per cent. will nof precipitate an attack (Folin and others, 1924). 
Perhaps the greatest confusion lies in our understanding of the relationship of an acute attack to the level of circulating urate. The most important study in this connexion is that of Jacobson (1938), who makes the point that it is inherently impossible to obtain information from a study of individual cases and that only a statistical investigation will give the necessary evidence. He admits that his own data were obtained under conditions which only approximate to the ideal desiderata of frequent observations between and during attacks under controlled conditions of diet and medication. He was only able to detect significant differences between the readings obtained during asymptomatic and attack periods by comparing the observations during an arbitrary 3-day period before the attack with the remainder, and his findings suggested that the serum uric acid fell during the attack period.

Urinary uric acid estimations are subject to many of the same difficulties as blood studies; and, moreover, endogenous and exogenous uric acid may influence excretion independently (BrøchnerMortensen, 1937). In addition, caffein, theophylline, and theobromine may be oxidized to methylated uric acid in the urine, and this may give a reaction to phosphotungstic acid. It is possible that the alleged uricosuric action of these substances is due to this effect (Buchanan and others, 1945).

It has been suggested that an acute paroxysm of gout may be associated with changes in uric acid excretion. Osler (Osler and McCrae, 1920) not only claimed that the blood uric acid is higher during an attack but that the output of uric acid is low during the intervals and rises at the onset. Talbott and others (1935) and Talbott and Coombs (1938b) describe a "gout cycle", in which a cyclic disturbance of electrolyte balance occurs in gouty subjects, but Levin and others (1953) were unable to confirm their findings.

Probenecid ("Benemid").-After the incidental finding that caronamide, had a uricosuric action (Wolfson and others, 1948), Boger and others (1950) showed that p-(di-n-propylsulphamyl)-benzoic acid (probenecid, "Benemid") had a similar and more potent effect, and appeared to be less toxic (Boger and Crosson, 1950). This substance is presumed to act by interference with renal tubular mechanisms, bringing about reabsorption of urate from glomerular fluid; its uricosuric action is well documented (Gutman and Yü, 1951; Talbott and others, 1951; Talbott, 1951), whilst its toxic effect on the kidney appears to be negligible (Sirota and others, 1952a, b). Of particular interest were the side-effects noted, which included the occurrence of acute attacks of gout in some cases. Gutman and Yü (1951) found, for example, that six of eighteen cases treated with probenecid $2 \mathrm{~g}$. daily developed acute attacks within a few days. This substance, therefore, a potent and non-toxic uricosuric agent, provided an opportunity to study uric acid excretion and associated changes of blood levels in gouty subjects, and of the seven cases described in the present study, six had acute attacks whilst under investigation.

\section{Methods}

All patients except Case 3 were observed as in-patients. Free fluid intake was allowed without special dietary restrictions, except that patients were restricted to the standard hospital diet to the greatest practicable extent. The biochemical methods used are shown in Table I, the upper limit of normal being taken as $4 \mathrm{mg}$. $/ 100 \mathrm{ml}$. in the blood and $6 \mathrm{mg}$. $/ 100 \mathrm{ml}$. in the plasma or serum. Aspirin and other salicylates were excluded.

TABLE I

CLINICAL MATERIAL

\begin{tabular}{|c|c|c|c|c|c|}
\hline $\begin{array}{l}\text { Case } \\
\text { No. }\end{array}$ & Sex & $\begin{array}{c}\text { Age } \\
\text { (yrs) }\end{array}$ & $\begin{array}{c}\text { Duration } \\
\text { of Gout } \\
\text { (yrs) }\end{array}$ & $\begin{array}{l}\text { Period of } \\
\text { Study } \\
\text { (days) }\end{array}$ & Method \\
\hline 1 & $\mathbf{M}$ & 59 & 27 & 32 & $\begin{array}{l}\text { Blood: Folin and } \\
\text { Trimble (1924) } \\
\text { Urine: Folin and } \\
\text { Schaffer (Plimmer, } \\
\text { 1918) }\end{array}$ \\
\hline 2 & $\mathbf{M}$ & 43 & 10 & 45 & Bidmead (1951) \\
\hline 3 & $\mathbf{M}$ & 60 & 25 & 21 & $\begin{array}{l}\text { Blood: Folin and } \\
\text { Trimble (1924) } \\
\text { Urine: Folin and } \\
\text { Schaffer (Plimmer, } \\
\text { 1918) }\end{array}$ \\
\hline 4 & $\mathbf{M}$ & 43 & 23 & 11 & Bidmead (1951) \\
\hline 5 & $\mathbf{M}$ & 52 & 3 & 13 & Folin (1934) \\
\hline 6 & $\mathbf{M}$ & 56 & 15 & 86 & Bidmead (1951) \\
\hline 7 & $\mathbf{M}$ & 46 & 5 & 7 & $\begin{array}{l}\text { Blood: Folin (1933) } \\
\text { Urine: Benedict and } \\
\text { Franke (1922) }\end{array}$ \\
\hline
\end{tabular}

\section{Case Reports}

Three illustrative cases are described and the findings in the other four cases are summarized.

Case 2, male, aged 43, had been found at the age of 21 to have albuminuria and was diagnosed as suffering from nephritis. He had been treated since then with a low protein diet, although albuminuria had persisted. His first attack of gout occurred in the big toe at the age of 33 . At the age of 38 splenomegaly was noted and he was found to be anaemic. Despite much investigation in various countries the nature of his anaemia was never established. At the same time small tophi appeared on his ears. By the age of $\mathbf{4 0}$ his attacks of gout were affecting his hands and wrists, lasting from 2 to 3 weeks, with remissions of about the same length. Five months 
before admission, tophi appeared on the left 2 nd metacarpophalangeal joint, the left 5 th proximal interphalangeal joint, and in both olecranon bursae. He had typical large tophi on both hands and elbows, with small tophi on both ears. His mucous membranes were pale and there were small glands in both axillae, the spleen being enlarged to a hand's breadth below the costal margin.

Haemoglobin 67 per cent.; red blood count 5,100,000 per c.mm.; colour index $0 \cdot 66$; white blood count 3,100 per c.mm.; differential count normal. No abnormal white cells were present.

Erythrocyte sedimentation rate $6 \mathrm{~mm}$./hr (Wintrobe) uncorrected.

Urine fixed specific gravity of 1,006 , with protein ++ but no abnormal cells or casts. Urea clearance (Van Slyke) 27 per cent. of maximum normal, blood urea $70 \mathrm{mg}$. per cent.

$X$ rays of hands and feet showed marked punchedout erosions characteristic of gout.

This patient was studied for 45 days, a control period of 8 days, treatment with probenecid $1 \mathrm{~g}$. daily for 19 days, and with $1.5 \mathrm{~g}$. daily for 15 days. At the end of this period he was treated with $2 \mathrm{~g}$. probenecid daily for 3 days only.

On the 7th day of his control period he developed a severe polyarticular attack of gout, the serum uric acid rising from $7 \cdot 1$ to $12 \cdot 8 \mathrm{mg}$. per cent., and the blood urea from 70 to $105 \mathrm{mg}$. per cent. on the 10th day. He was therefore given colchicine 1/60 gr. 2-hrly for six doses, and probenecid $1 \mathrm{~g}$. daily. Colchicine was continued after the initial loading dose in doses of $1 / 120 \mathrm{gr}$. three times a day for the rest of his period in hospital. The serum uric acid fell by the 15 th day to $5.9 \mathrm{mg}$. per cent., the blood urea continuing to rise until the 14th day to $118 \mathrm{mg}$. per cent., and thereafter falling slowly to its previous level. On the 28th day after admission the dose of probenecid was increased to $1 \cdot 5 \mathrm{~g}$. daily, and tophectomy was carried out on the 36 th day, both olecranon bursae being removed. During the course of treatment on the 18th day his renal function was reassessed, his urea clearance being $21 \cdot 5$ per cent. of maximum normal. Detailed figures are given in Table II and illustrated in Fig. 1 (opposite).

A striking feature of this case was the marked increase in the serum uric acid in association with the acute attack. However, the patient had a grossly deficient renal function and the blood urea was also rising during this period, and it is possible that the increasing serund uric acid is simply a reflection of renal failure. During? the whole period of study an excess of uric acid amount ing to $6,623 \mathrm{mg}$. was excreted. The tophi containe $\&$ approximately $1,300 \mathrm{mg}$. uric acid, a relatively sma禺 amount in comparison with the excess excreted in the urine. This point is commented on below.

No definite conclusion can be made from this case as to the specific problem of the relationship o uric acid to the acute paroxysm of gout, for, althoughlarge changes in serum uric acid levels occurred at the time of the acute attack, the presence of renatu failure with the rising blood urea complicates the picture to a degree which prevents the drawing of any conclusions relevant to this particular problem: However, with further experience in treating patients with probenecid it was confirmed that not infrequently an acute attack would develop during the first few days, at a time when the blood urig acid level had been brought to normal. This is illustrated in Case 5.

Case 5, male, aged 52 (Fig. 2, overleaf, and Table II P, opposite), had his first attack of gout 3 years previously i $\overrightarrow{0}$ one big toe, with a characteristic onset, and 6 months lates he had had a similar attack in the right wrist, followed by other attacks. The present attack had developed 6 week previously in the right wrist. On admission there was swelling and extreme tenderness of both the right wris̄ and the right elbow. There were no tophi. At thg outset of uric acid studies he was at the stage when af acute exacerbation of his attack was just settling, leaving him with considerable residual symptoms. During the 6-day control period his mean plasma uric acid was $6.6 \mathrm{mg}$. per cent. and his mean urinary uric acid output was $1,005 \mathrm{mg} .24 \mathrm{hrs}$. On the $2 \mathrm{nd}$ day he was given. colchicine in full doses, and subsequently $1 / 120 \mathrm{gr}$. twice daily. During probenecid administration the output of uric acid per 24 hours increased to $1,920 \mathrm{mg}$., and the total excess excreted was $5,490 \mathrm{mg}$. in 6 days. Ther was a fall in plasma uric acid levels from $6 \cdot 2 \mathrm{mg}$. peo cent. on the day before treatment to $4.0 \mathrm{mg}$. per cent. op the 4 th day.

TABLE II

SERUM URIC ACID AND URINARY URIC ACID OBSERVATIONS IN CASE 2

Acute attack of gout occurred on Day 7, reaching maximum on Day 9. On Day 9 1/60 gr. colchicine was given 2-hrly for six doses, and thereafter $1 / 120 \mathrm{gr}$. three times daily. Tophectomy was carried out on Day 36.

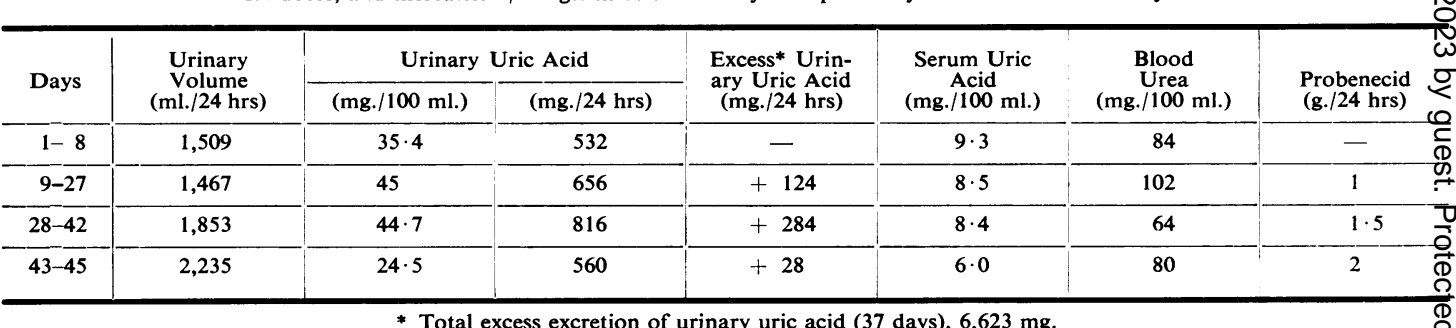

* Total excess excretion of urinary uric acid (37 days), 6,623 mg. 
Uू

BENEMID

$\sqrt{1 \mathrm{~g} .124 \mathrm{hrs}} \quad \downarrow \quad 1.5 \mathrm{~g} .124 \mathrm{hrs} \quad 2 \mathrm{~g} / 24 \mathrm{hrs}$

峞导
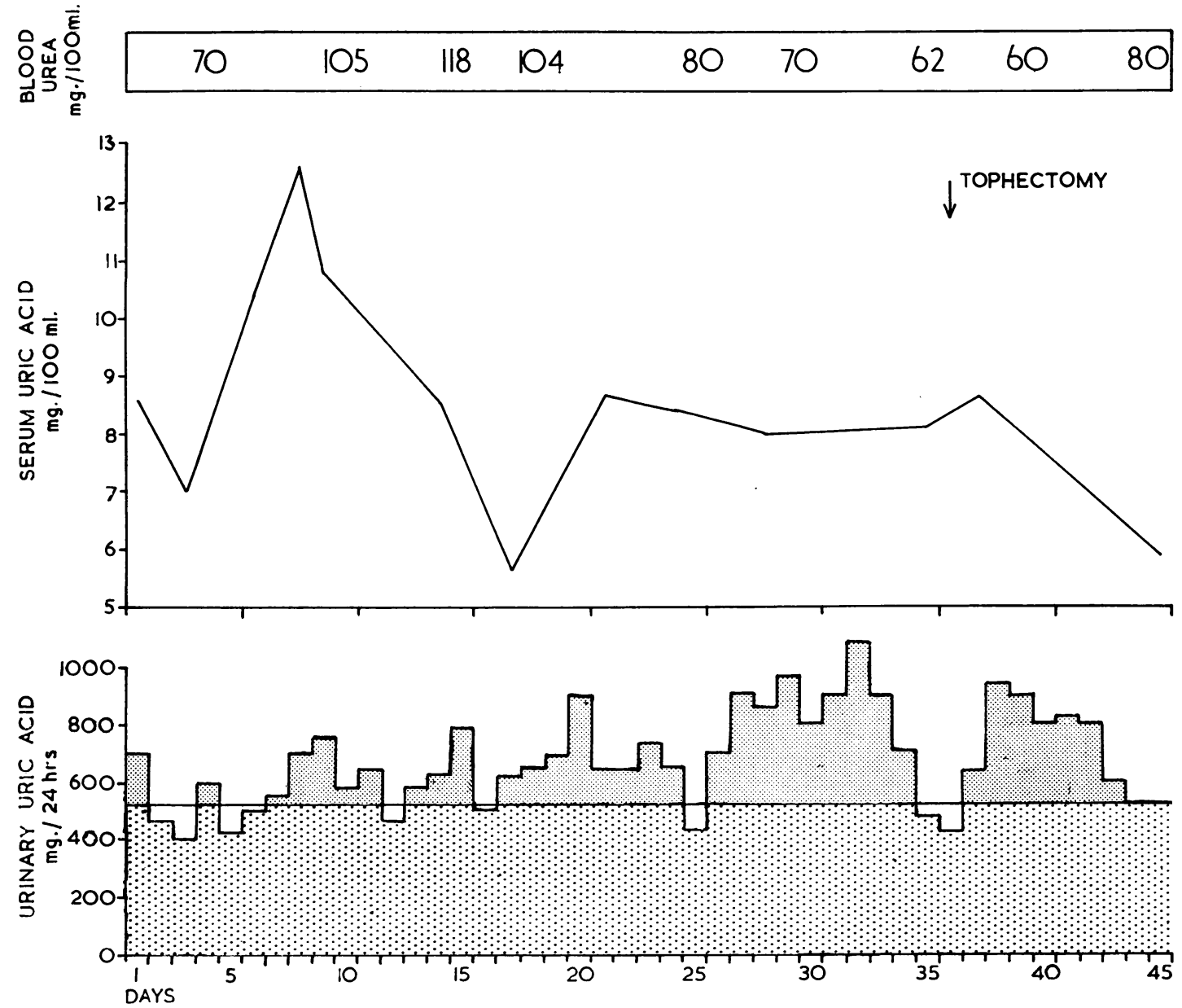

Fig. 1.-Case 2. Serum uric acid and urinary uric acid observations during 45 days (mean urinary uric acid during control period, $532 \mathrm{mg} . / 24 \mathrm{hrs})$.

TABLE III

PLASMA URIC ACID AND URINARY URIC ACID OBSERVATIONS IN CASE 5

\begin{tabular}{|c|c|c|c|c|c|c|}
\hline \multirow[b]{2}{*}{ Days } & \multirow{2}{*}{$\begin{array}{c}\text { Urinary Uric } \\
\text { Acid } \\
\text { (mg./24 hrs) }\end{array}$} & \multirow{2}{*}{$\begin{array}{c}\text { Excess }+ \text { Urinary } \\
\text { Uric Acid } \\
\text { (mg./24 hrs) }\end{array}$} & \multirow{2}{*}{$\begin{array}{l}\text { Plasma Uric } \\
\text { Acid } \\
(\mathrm{mg} . / 100 \mathrm{ml} .)\end{array}$} & \multicolumn{2}{|c|}{ Dosage } & \multirow[b]{2}{*}{ Symptoms } \\
\hline & & & & $\begin{array}{c}\text { Colchicine } \\
\text { (gr. } 1 / 120 / 24 \mathrm{hrs})\end{array}$ & $\begin{array}{l}\text { Probenecid } \\
\text { (g./24 hrs) }\end{array}$ & \\
\hline $1-6$ & 1,005 & - & $6 \cdot 6$ & $2 *$ & - & Settling \\
\hline $7-12$ & 1,920 & -. 915 & $4 \cdot 2$ & 2 & 2 & $\begin{array}{l}\text { Acute flare on } \\
\text { days } 9,10 \text { and } 11\end{array}$ \\
\hline
\end{tabular}


岁

崖造
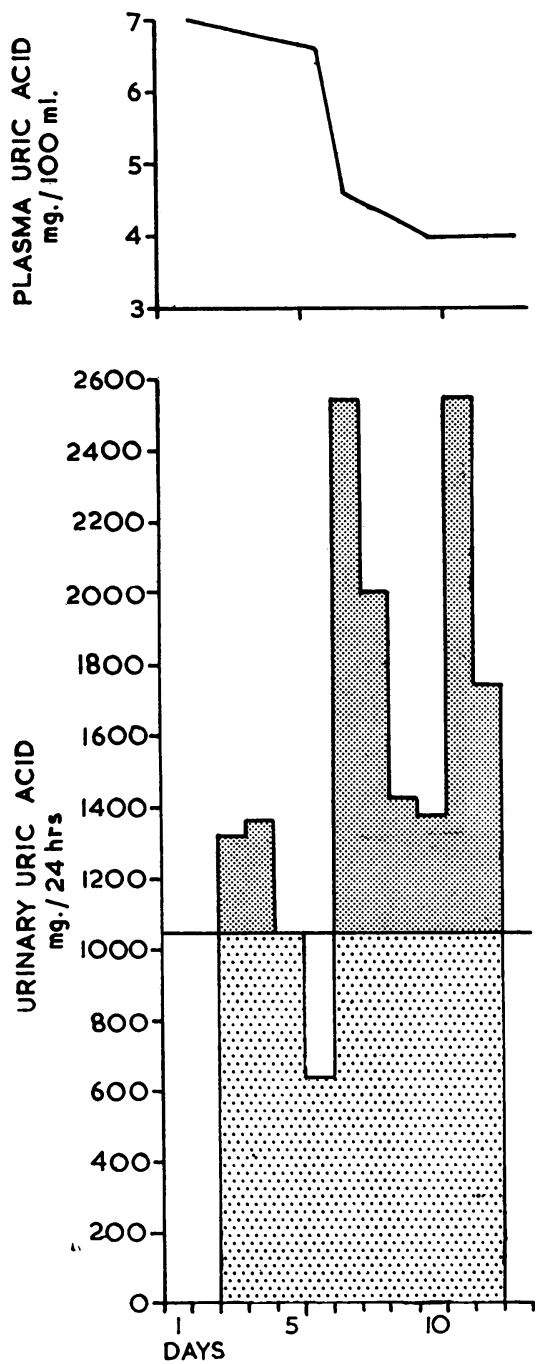

Fig. 2.-Case 5. Plasma uric acid and urinary uric acid observations during 12 days (mean urinary uric acid during control period, 1,005 mg./24 hrs).

On the 3rd day of treatment he had a definite acute flare in his wrist.

Case 6, male, aged 56 (Figs 3 and 4 and Table IV), was a severe case of gout with polyarticular attacks of long duration, his first attack having occurred 15 years pre-

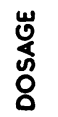

BENEMID $2 \mathrm{~g} . / 24 \mathrm{hrs}$

COLCHICINE

屴䒨
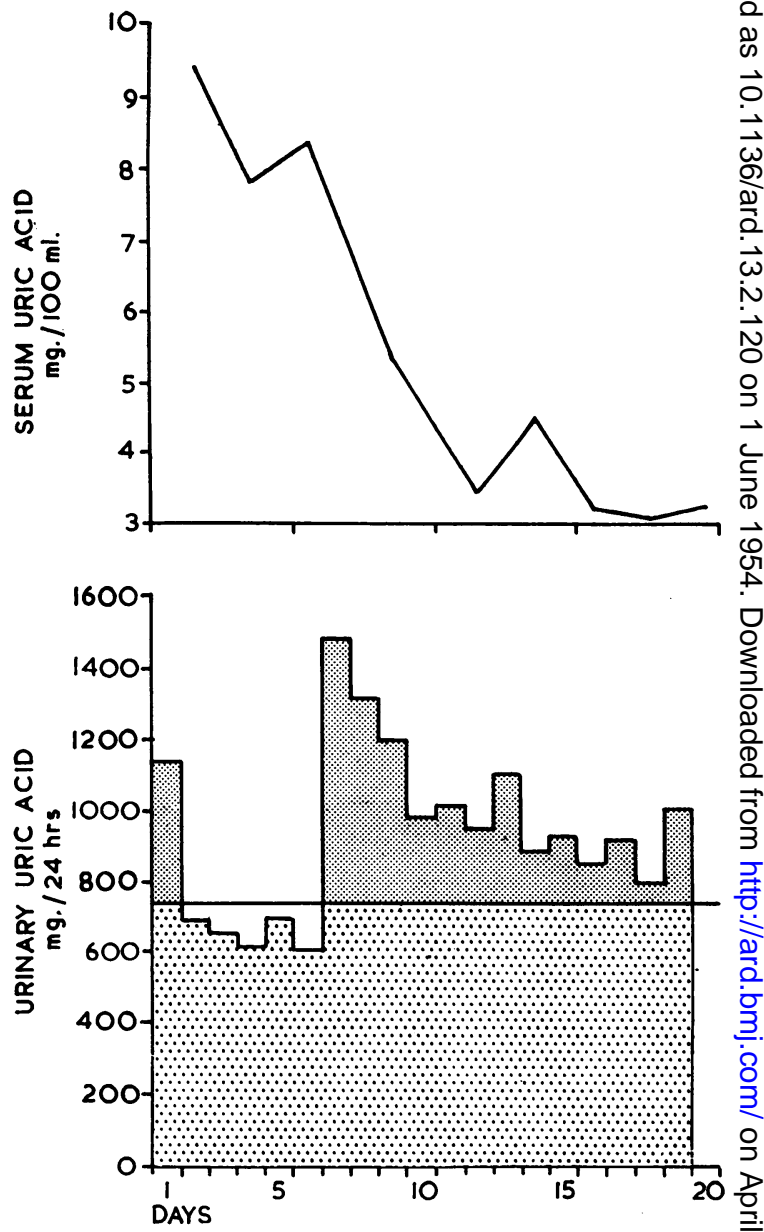

Fig. 3.-Case 6. Serum uric acid and urinary uric acid findings $\mathrm{N}$ during 19 days' observation (mean urinary uric acid during control $\sigma$ period, $745 \mathrm{mg} . / 24 \mathrm{hrs})$.

N

viously. The knees, wrists, and fingers were involved, $\underset{\mathrm{C}}{\mathrm{N}}$ and he had developed tophi on both ears. He had been $\sigma$ on a low protein diet for the previous 5 years. There

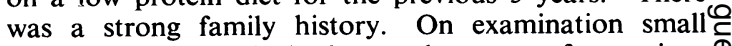
tophi were present in both ears, but, apart from minor $\stackrel{\Phi}{\Phi}$ degenerative changes in both knees and first metatarso- $\cdot$ phalangeal joints, his joints appeared normal.

Blood urea was 52 and $33 \mathrm{mg}$. per cent. on two

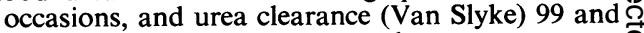
96 per cent. of average normal. 
ญू
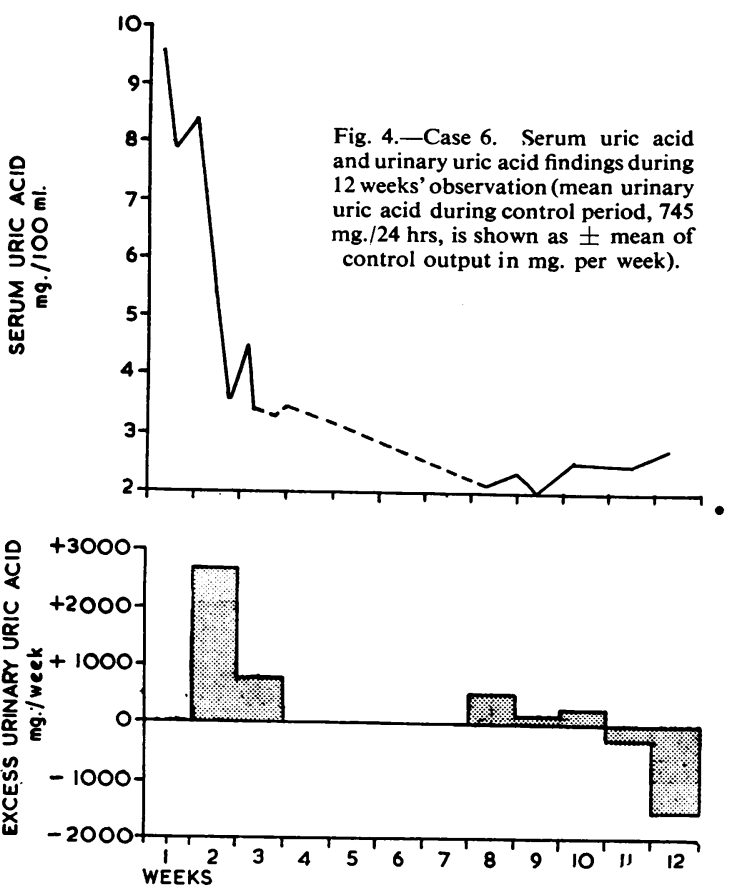

Examination of material from a tophus showed crystals of sodium biurate with a positive murexide test.

$X$ rays of the hands and feet showed small punchedout areas in both first metatarsophalangeal joints with osteo-arthritic changes.

During 15 days of therapy $3,563 \mathrm{mg}$. urinary uric acid was excreted over and above the anticipated excretion on the basis of control values. Serum uric acid fell quite rapidly from a maximum of 9.4 to $3.3 \mathrm{mg}$. per cent. on the 5th day of treatment. On Day 14 the patient developed an acute attack of gout in one big toe and on that day his serum uric acid was normal at $4.6 \mathrm{mg}$. per cent. On Day 17 a more intense attack developed and he took colchicine in full doses. The serum uric acid over this period was $3 \cdot 4,3 \cdot 3$, and $3 \cdot 4 \mathrm{mg}$. per cent. He was discharged on the 22 nd day on $2 \mathrm{~g}$. probenecid daily. Within 24 hours of discharge he developed an intense polyarticular attack, but continued with probenecid, and colchicine 1/120 gr. four times daily. He was re-admitted 4 weeks after discharge, still with a very intense polyarticular attack. During the first week after admission (Days 52 to 58) he was still excreting a mean daily excess of $83.0 \mathrm{mg} . / 24 \mathrm{hrs}$, and his serum uric acid was $2 \cdot 2$ and $2 \cdot 3 \mathrm{mg}$. per cent. on two occasions. The attack gradually settled, and during the following 3 weeks the excretion of uric acid in the urine did not deviate by more than a few mg. from normal, the serum uric acid remaining at about the same level. He was treated briefly with phenylbutazone in the hopes of relieving his attack, but it is not possible to say whether this was effective. During the first 5-day period after discontinuing probenecid (Days 80 to 84 ), a total of $1,535 \mathrm{mg}$. uric acid was retained, and he had an acute attack of gout which was controlled with colchicine.

TABLE IV

SERUM URIC ACID AND URINARY URIC ACID OBSERVATIONS IN CASE 6

\begin{tabular}{|c|c|c|c|c|c|c|c|c|c|}
\hline \multirow[b]{2}{*}{ Days } & \multirow[b]{2}{*}{$\begin{array}{c}\text { Urinary } \\
\text { Volume } \\
\text { (ml./24 hrs) }\end{array}$} & \multicolumn{2}{|c|}{ Urinary Uric Acid } & \multirow{2}{*}{$\begin{array}{c}\text { Excess } \\
\text { Urinary } \\
\text { Uric Acid } \\
\text { (mg./24 hrs) }\end{array}$} & \multirow{2}{*}{$\begin{array}{l}\text { Serum } \\
\text { Uric Acid } \\
\text { (mg./100 } \\
\text { ml.) }\end{array}$} & \multicolumn{3}{|c|}{ Dosage } & \multirow[b]{2}{*}{ Symptoms } \\
\hline & & $\underset{\text { ml. }}{(\mathrm{mg} . / 100}$ & $\begin{array}{c}\text { (mg./24 } \\
\text { hrs) }\end{array}$ & & & $\begin{array}{l}\text { Colchicine } \\
\text { (gr. } 1 / 120 / \\
24 \text { hrs) }\end{array}$ & $\begin{array}{l}\text { Probenecid } \\
(\mathrm{g} . / 24 \mathrm{hrs})\end{array}$ & $\begin{array}{c}\text { Phenyl- } \\
\text { butazone } \\
\text { (mg./24 hrs) }\end{array}$ & \\
\hline $1-6$ & 3,177 & 23 & 745 & - & $8 \cdot 6$ & - & - & - & Nil \\
\hline $7-13$ & 2,764 & $40 \cdot 6$ & 1,134 & +389 & $4 \cdot 6$ & - & 2 & - & Nil \\
\hline $14-21$ & 2,643 & 33 & 850 & +105 & $3 \cdot 7$ & $\begin{array}{c}7 \\
\text { (Day 17) }\end{array}$ & 2 & - & $\begin{array}{l}\text { Acute mon- } \\
\text { articular attack }\end{array}$ \\
\hline $22-51$ & - & - & - & - & - & 4 & 2 & - & $\begin{array}{l}\text { Severe poly- } \\
\text { articular attack }\end{array}$ \\
\hline $52-58$ & 1,998 & 42 & 828 & +83 & $2 \cdot 25$ & - & 2 & $\begin{array}{c}800 \\
\text { (Days 55-58) }\end{array}$ & $\begin{array}{l}\text { Severe poly- } \\
\text { articular attack }\end{array}$ \\
\hline $59-65$ & 2,387 & $32 \cdot 6$ & 756 & +11 & $2 \cdot 1$ & - & 2 & $\begin{array}{c}800 \\
\text { (Days 59, 63, } \\
64)\end{array}$ & Attack settling \\
\hline $66-72$ & 2,263 & $34 \cdot 9$ & 774 & +29 & $2 \cdot 5$ & - & 2 & $\begin{array}{c}200 \\
\text { (Days } 67,68)\end{array}$ & Residual pain \\
\hline 73-79 & 2,407 & $30 \cdot 6$ & 709 & -36 & $2 \cdot 5$ & - & 2 & - & Residual pain \\
\hline $80-84$ & 1,811 & $23 \cdot 4$ & 438 & -307 & $2 \cdot 9$ & $\begin{array}{c}8 \\
\text { (Day 84) }\end{array}$ & - & - & $\begin{array}{l}\text { Acute mon- } \\
\text { articular attack }\end{array}$ \\
\hline
\end{tabular}

* Total excess excretion of urinary uric acid, Days 7-21, 3,563 my.

+ Estimated total excess uric acid excretion, Days 7-79, 7,953 mg. 
TABLE V

SUMMARY OF FINDINGS IN CASES 1, 3, 4, AND 7

\begin{tabular}{|c|c|c|c|c|c|c|c|c|}
\hline \multirow{2}{*}{$\begin{array}{l}\text { Case } \\
\text { No. }\end{array}$} & \multicolumn{3}{|c|}{ Control Period } & \multicolumn{4}{|c|}{ Probenecid ( $2 \mathrm{~g} . / 24 \mathrm{hrs}$ ) } & \multirow{2}{*}{$\begin{array}{c}\text { Onset of } \\
\text { Acute Attack } \\
\text { (day of } \\
\text { probenecid } \\
\text { administration) }\end{array}$} \\
\hline & Days & $\begin{array}{c}\text { Serum } \\
\text { Uric Acid } \\
\text { (mg./100 ml.) }\end{array}$ & $\begin{array}{c}\text { Urinary } \\
\text { Uric Acid } \\
\text { (mg./24 hrs) }\end{array}$ & Days & $\begin{array}{c}\text { Serum } \\
\text { Uric Acid } \\
(\mathrm{mg} . / 100 \mathrm{ml} .)\end{array}$ & $\begin{array}{c}\text { Urinary } \\
\text { Uric Acid } \\
\text { (mg./24 hrs) }\end{array}$ & $\begin{array}{c}\text { Total Excess } \\
\text { Urinary Uric Acid } \\
\text { (mg.) }\end{array}$ & \\
\hline 1 & $\begin{array}{l}10 \\
+\quad 10\end{array}$ & $6 \cdot 9(6)$ & 329 & 13 & $4 \cdot 5(11)$ & 494 & 2,245 & - \\
\hline 3 & 9 & $7 \cdot 1(2)$ & 275 & 11 & $3 \cdot 4$ (2) & 486 & 2,321 & 6 \\
\hline 4 & 4 & $9 \cdot 0(1)$ & 680 & 7 & $4 \cdot 9 \quad(3)$ & 911 & 1,617 & 5 \\
\hline 7 & $i$ & $4 \cdot 7^{*}(2)$ & 743 & 6 & $3 \cdot 4^{*}$ & 1,226 & 2,417 & 2 \\
\hline
\end{tabular}

Number of serum uric acid estimations given in brackets.

* Blood uric acid.

This case illustrates quite clearly that an attack of gout can occur when the serum uric acid levels have been brought to well below normal limits. The long-term studies here enable quantitative calculations to be made which are discussed below.

Cases 1, 3, 4, and 7.-These all gave essentially similar results, except that no acute attack occurred in Case 1. The findings are summarized in Table V.

\section{Discussion}

These investigations provided an opportunity of studying the relationship of uric acid to gout from two aspects:

(1) Relationship of the acute paroxysm of gout to blood levels,

(2) Quantitative studies.

Relationship of Acute Paroxysm of Gout to Blood Levels.-Cases 3, 4, 6, and 7 had acute attacks whilst under observation during probenecid therapy. Case 5 had an exacerbation of an acute attack, and Cases 2 and 4 developed an attack during the period of initial observation.

Case 3.- Unfortunately no observations of the blood levels were possible during the attack, which began on the 7th day of Benemid administration. Two days before this attack began, this patient's serum uric acid was $3.2 \mathrm{mg}$. per cent. compared with $6 \cdot 6$ and $7 \cdot 6 \mathrm{mg}$. per cent. during the control period; 10 days after the attack began and 6 days after withdrawal of probenecid, the serum uric acid had risen to $7.4 \mathrm{mg}$. per cent. From the time of his last blood estimation to the height of the attack he excreted uric acid at a rate well above his mean control level (275 mg. $/ 24 \mathrm{hrs})$, a total excess of $478 \mathrm{mg}$., and he continued to excrete an excess throughout the period of probenecid administration. It seems probable, therefore, that his serum uric acid was normal during the attack.

Case 4.-This patient had two attacks during the 11 days of study. Again no blood estimation was carried out at the critical time, at the onset or at the height of the attack. On the 3rd day of his first attack (during the control period) his serum uric acid was $9 \mathrm{mg}$. per cent. On the day before his attack, during probenecid therapy, it was $4.6 \mathrm{mg}$. per cent., and on that and the succeeding two days he excreted a total excess of $1,500 \mathrm{mg}$. uric acid.

Case 6.-This case demonstrates very clearly the occurrence of an acute attack at a time when the level of circulating uric acid had been brought to normal. On re-admission a month later with a very severe polyarticular attack his serum uric acid had fallen still further to $2 \cdot 2$ and $2 \cdot 3 \mathrm{mg} . / 100 \mathrm{ml}$.

Case 7.-This case demonstrated a similar phenomenon. The blood uric acid during a 2-day control period was 4.4 and $5 \mathrm{mg}$. per cent., and at the height of his attack on the 4th day of probenecid therapy it had fallen to $2.7 \mathrm{mg}$. per cent. (Fig. 5, opposite).

Case 2.-This patient developed his acute attack during the control period, but the findings are of less value in this connexion in view of his gross renal failure. His serum uric acid rose rapidly from 8.6 and $7 \cdot 1$ to $10.4 \mathrm{mg} . / 100 \mathrm{ml}$. on the day before the attack began, and reached a maximum of $12.8 \mathrm{mg}$. per cent. when probenecid administration was begun. His blood urea also rose from 70 to $96 \mathrm{mg} . / 100 \mathrm{ml}$. on the $2 \mathrm{nd}$ day of his attack, 105 on the 4th day, and 118 on the 8th day. It may therefore be that the rising serum uric acid was associated with renal failure and it is difficult to draw any conclusions.

Case 5.-This patient had already developed an $\mathcal{N}$ attack of gout when admitted, but on the 3rd day of $N$ probenecid administration he developed an acute exacer- 용 bation. His plasma uric acid had been 7 and $6.2 \mathrm{mg}$. $\mathrm{\omega}$ per cent. during the control period. On the day before the exacerbation developed it was $4.6 \mathrm{mg}$. per cent., and on the 2 nd day of the attack $4 \mathrm{mg}$. per cent.

It is evident that, whatever the changes in blood levels in a naturally occurring attack of gout, acute paroxysms can occur at a time when the level has been sharply brought to normal. This finding $\overrightarrow{0}$ 

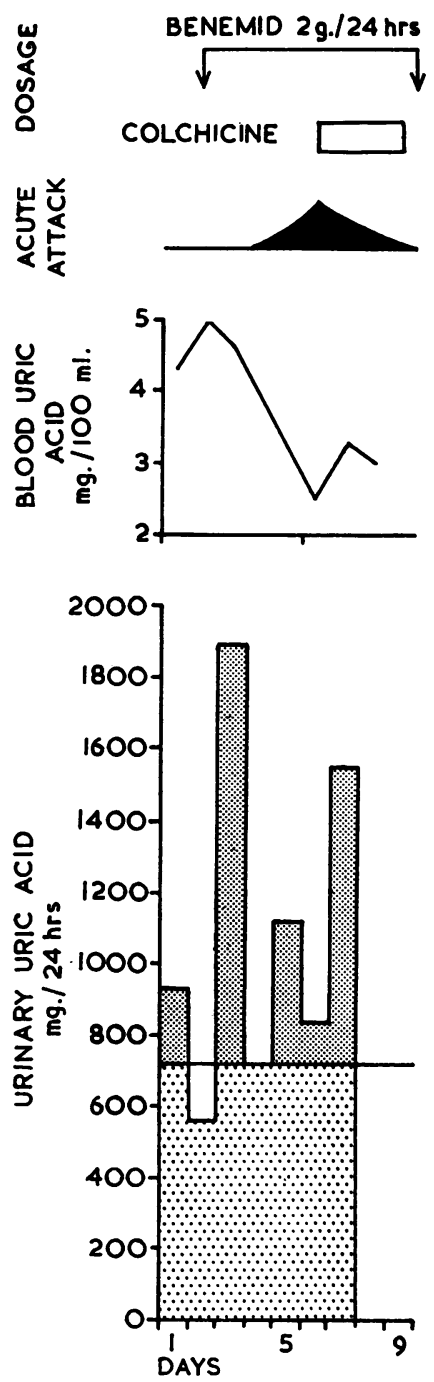

Fig. 5.-Case 7. Blood uric acid and urinary uric acid studies during 7 days (mean urinary uric acid during control period, 743 mg./24 hrs).

renders it difficult to believe that uric acid per se can be responsible for initiating the acute paroxysm of gout.

Quantitative Studies.-It is possible to compare the total excess of uric acid excreted with the change in plasma uric acid in Cases 1, 3, 4, 5, and 6. Case 2 is excluded because of the renal failure and the acute attack at the onset of treatment, and Case 7 is excluded because the estimations were made on whole blood. For convenience, the first 5 days of probenecid administration only are considered. As anticipated, the calculated loss of uric acid from the plasma is very much less than the excess excreted. Estimating the plasma volume at 0.05 body weight, the amount lost in 5 days of probenecid therapy is calculated as varying from 191 to $101 \mathrm{mg}$. (mean, $149 \mathrm{mg}$.). At the same time, the excess appearing in the urine over the same period lies between 4,755 and $768 \mathrm{mg}$. (mean, 2,136 mg.).

A similar, though smaller, discrepancy occurs if calculations are made on the uric acid contained in the extracellular fluid $(0.2$ body weight $)$. On this basis, the loss of extracellular uric acid in these cases amounted to from 757 to $398 \mathrm{mg}$. (mean, $588 \mathrm{mg}$.). Table VI shows a similar analysis based on total body uric acid calculations. These are estimated on the assumption that uric acid is equally distributed throughout the body fluids (an assumption which is liable to serious objections which are discussed below), the total body fluid being estimated by the formula body water $=0.7$ body weight. On this basis the fall in calculated body urate varies between 2,645 and 1,393 $\mathrm{mg}$. (mean, 2,173 mg.), whilst the excretion excess lies between 4,755 and $768 \mathrm{mg}$. (mean, 2,136 mg.). In all these cases, except Case 5, there was a discrepancy in the opposite direction, and previous quantitative studies of this nature have given essentially similar results. Graham (1920) also noted a similar discrepancy and concluded that the extra uric acid could not possibly have come from the blood alone, but might be accounted for in the amount distributed in solution in the tissue fluids. He was perhaps the first to draw attention to the possibility that uric acid in the solid phase might play a part. He also determined the total body uric acid on the assumption that it is equally distributed in the body fluids, assuming that water comprised 90 per cent. of the body weight. On this basis his patient had totals of 1,200 and $2,500 \mathrm{mg}$. uric acid on two occasions. In one experiment the estimated change in total body uric acid approxi-

TABLE VI

EFFECT OF 5 DAYS' PROBENECID ADMINISTRATION ON CALCULATED TOTAL BODY URIC ACID

Comparison with excess urinary excretion during the same period

\begin{tabular}{|c|c|c|c|c|}
\hline $\begin{array}{l}\text { Case } \\
\text { No. }\end{array}$ & $\begin{array}{l}\text { Weight } \\
\text { (kg.) }\end{array}$ & $\begin{array}{l}\text { Loss of Body } \\
\text { Uric Acid } \\
\text { (mg.) }\end{array}$ & $\begin{array}{c}\text { Excess } \\
\text { Urinary Uric } \\
\text { Acid Excreted } \\
\text { (mg.) }\end{array}$ & $\begin{array}{c}\text { Discrepancy } \\
\text { (urinary excess } \\
\text { minus calculated } \\
\text { change) (mg.) }\end{array}$ \\
\hline 1 & $93 \cdot 2$ & 2,778 & 1,455 & $-1,323$ \\
\hline 3 & $66 \cdot 8$ & 1,558 & 768 & -790 \\
\hline 4 & $85 \cdot 9$ & 2,645 & 1,480 & $-1,165$ \\
\hline 5 & $90 \cdot 5$ & 1,393 & 4,755 & $+3,362$ \\
\hline 6 & $77 \cdot 3$ & 2,489 & 2,222 & $-\quad 267$ \\
\hline Mean & $82 \cdot 7$ & 2,173 & 2,136 & 37 \\
\hline
\end{tabular}


mated to the excess excreted, in another the decrease was greater than the excess excreted. One possible source of error to which he draws attention is that the flow of uric acid from the tissue fluids to the blood might require some time for equilibrium to develop, so that the concentration of uric acid in the plasma does not reflect the concentration of uric acid in the body fluids as a whole. Thus, calculations of total body uric acid on the basis of blood readings, even supposing the other assumption is correct, may be liable to serious error. The discrepancy here occurs (except for Case 5) in the same direction as Graham's, i.e. less uric acid was excreted in excess than the calculated body changes would account for. These discrepancies may well be due to the unreliability of calculations of body uric acid for the reasons given by Graham. Table VII shows similar calculations made in the same way on four non-gouty cases given $2 \mathrm{~g}$. probenecid daily for 5 days. The response during this period shows no striking difference when compared with that of gouty subjects. The excess amount of uric acid appearing in the urine averaged $1,603 \mathrm{mg}$. as compared with $2,136 \mathrm{mg}$. in the gouty subjects, but it will be noted that the average body weight of the controls was $70.7 \mathrm{~kg}$., and the gouty subjects weighed on the average $12 \mathrm{~kg}$. (26 lb.) more. No differences in this respect could be detected which would be of use in differential diagnosis in individual cases, although it is possible that longer term studies might be of value.

In the one patient (Case 6) who was followed for a longer term, it is more probable that equilibrium is achieved. In this particular case a gap of 31 days occurred, however, when he was discharged from hospital, so that an approximation can only be made of the total excess uric acid excreted by assuming that it was at the rate of the mean of Weeks 3 and 8 (i.e. $+94 \mathrm{mg} . / 24 \mathrm{hrs}$ ). During Weeks 9,10 , and 11 , the daily excretion reached a mean of $+3.6 \mathrm{mg}$./ $24 \mathrm{hrs}$ above the control values, which may be considered as within the experimental error. The total excess of uric acid excreted amounted to 7,953 mg., but the calculated change of body urate amounts to only $3,139 \mathrm{mg}$. There would appear to be a difference in this case as compared with the calculations based on short-term studies, since the excess of excretion over the calculated change in total body urate amounts to $4,814 \mathrm{mg}$. It seems likely that the long-term study gives a more reliable result. If one can accept, therefore, that in this case equilibrium had been achieved, the discrepancy found lends support to the hypothesis that uric acid in the solid phase is in equilibrium with body fluid urate. It is necessary to emphasize, however, that the urinary uric acid has had to be estimated over the period of one month, which must leave an element of doubt in this conclusion.

The above calculations may be compared with those made from injecting isotopic uric acid labelled in the 1 and 3 positions with $\mathrm{N}-15$ (Benedict and others, 1949). The size of the pool in normal subjects was found to be about $1,200 \mathrm{mg}$., but in gouty subjects this was increased many times, sometimes fifteenfold, e.g. to 15,450 and $31,019 \mathrm{mg}$. (Benedict and others, 1950). The very size of the pool suggested that some at least of the uric acid must be in the solid phase. Benedict found very different figures for the concentration of uric acid in tissue fluids; in one case this amounted to $35 \cdot 1$ and $59.1 \mathrm{mg}$. per cent. These figures too are so high that solid uric acid deposits may well be involved.

Only in Case 6 was it possible to maintain the observations long enough to follow the urinary uric acid output until it reached approximately normal values. If we assume that uric acid deple-

TABLE VII

RESULTS OBTAINED IN FOUR CONTROL CASES GIVEN 2 g. PROBENECID DAILY FOR 5 DAYS

Calculated body uric acid changes correlated with observed urinary uric acid changes

\begin{tabular}{|c|c|c|c|c|c|c|c|c|}
\hline \multirow[b]{2}{*}{$\begin{array}{l}\text { Age } \\
\text { (yrs) }\end{array}$} & \multirow[b]{2}{*}{ Sex } & \multirow[b]{2}{*}{ Diagnosis } & \multirow[b]{2}{*}{$\begin{array}{l}\text { Weight } \\
\text { (kg.) }\end{array}$} & \multicolumn{3}{|c|}{ Calculated Total Body Uric Acid } & \multirow[b]{2}{*}{$\begin{array}{c}\text { Excess Urinary } \\
\text { Uric Acid } \\
\text { (mg.) }\end{array}$} & \multirow{2}{*}{$\begin{array}{c}\text { Discrepancy } \\
\text { (urinary excess } \\
\text { minus calculated } \\
\text { change) } \\
\text { (mg.) }\end{array}$} \\
\hline & & & & $\begin{array}{c}\text { Before } \\
\text { Administration } \\
\text { (mg.) }\end{array}$ & $\begin{array}{c}\text { After } \\
\text { Administration } \\
\text { (mg.) }\end{array}$ & (mg.) & & \\
\hline 44 & $\mathbf{M}$ & $\begin{array}{l}\text { Prolapsed inter- } \\
\text { vertebral disk }\end{array}$ & $65 \cdot 0$ & 2,457 & 955 & $-1,502$ & $+2,040$ & +538 \\
\hline 64 & $\mathbf{M}$ & $\begin{array}{l}\text { Prolapsed inter- } \\
\text { vertebral disk }\end{array}$ & $82 \cdot 7$ & 2,490 & 1,042 & $-1,448$ & $+1,370$ & -78 \\
\hline 69 & $\mathbf{M}$ & $\begin{array}{l}\text { Rheumatoid } \\
\text { arthritis }\end{array}$ & $72 \cdot 0$ & 2,117 & 1,512 & -605 & $+1,350$ & +745 \\
\hline \multirow[t]{2}{*}{61} & $\mathbf{M}$ & $\begin{array}{l}\text { Osteo- } \\
\text { arthritis }\end{array}$ & $63 \cdot 2$ & 1,591 & 442 & $-1,149$ & $+1,650$ & +501 \\
\hline & \multicolumn{2}{|c|}{ Mean } & $70 \cdot 7$ & 2,164 & 988 & $-1,176$ & $+1,603$ & +427 \\
\hline
\end{tabular}


tion had then occurred it is possible to calculate roughly the size of the miscible pool. The calculated total excess uric acid excreted amounted to $7,953 \mathrm{mg}$. uric acid in this case. This figure is of the same order as those of Benedict and others, and it is therefore possible that this patient's miscible pool was approximately this size. It must be borne in mind that the size of his remaining pool has not been calculated, a calculation which is possible in isotope dilution studies. In one gouty subject studied under similar conditions by Talbott (1951), using the isotope technique, a fall in pool size occurred as a result of probenecid administration from 2,205 to 1,622 mg., and in another (Bishop and others, 1951a, b) from 4,700 to $1,600 \mathrm{mg}$. These figures are of very much the same order as those in the present case.

Unfortunately in Case 2, which is the only other case in which a long-term study was possible, renal function was so impaired that uric acid depletion could not be obtained. Of particular interest in this case, however, was the carrying out of tophectomy on Day 36; it was after this operation that the serum uric acid fell from a mean of $8 \cdot 2 \mathrm{mg}$. per cent. during the previous 10 days to $6 \mathrm{mg}$. per cent. a week after operation. The amount of uric acid in the tophi was surprisingly small, amounting to $1,330 \mathrm{mg}$. This suggests that either these tophi were not acting as "banks" partly included in the miscible pool, or that they had been depleted by treatment with probenecid. A total excess of $4,700 \mathrm{mg}$. uric acid had already been excreted at the time of operation. In view of the fact that Yü and Gutman (1951) have produced evidence that gouty tophi may be mobilized by prolonged use of probenecid, it is clearly possible that this had occurred when the tophectomy was carried out, and the smallness of the amount of uric acid in the tophus does not therefore exclude the possibility that uric acid in the solid phase is in equilibrium with that in solution.

Relationship of Uric Acid to Acute Attack.-In considering the relationship of uric acid and gout, we have to account for the fact that no consistent relationship can be established between uric acid levels and acute gout; furthermore, the present study suggests that attacks of gout may regularly occur when the blood level has been brought to normal by the use of probenecid.

It is difficult to avoid the conclusion that uric acid itself is not responsible for the acute attack of gout. If this is accepted, then one possible explanation is that a precursor of uric acid is involved. This precursor may theoretically be normal or abnormal, and there is very little data on which to decide between these possibilities. The possible inter- mediate products in the formation of uric acid have been recently reviewed by Gutman (1953). The answer to this problem may lie in the action of colchicine, for it is possible that colchicine acts by blocking the formation of this hypothetical precursor. If such is the case, then this must be an abnormal precursor, since colchicine has no effect on plasma uric acid level. There is some evidence, however, of another metabolic route in the formation of uric acid in gouty subjects: using labelled glycine in one case, Shemin and Rittenberg (1947) found that glycine can be responsible for the nitrogen in the 7 position in uric acid in man. Benedict and others (1952), using N-15 labelled glycine, were therefore able to identify the uric acid in the urine from this source, following the administration of isotopic glycine. Their findings suggested that in gouty subjects a more rapid mechanism exists for the transformation of glycine into uric acid than in normals, and they suggest that this may occur via a different metabolic route. Such a hypothesis would be consistent with the findings of the present investigation that acute attacks of gout may occur when probenecid administration has produced a uric acid diuresis and brought the blood levels to normal, for it is possible that by removing the end product of the metabolic chain the formation of precursors might even be increased. It would also be consistent with the observations of Wood-Jones (1950) and Barnett (1951), who suggest that the basis of the acute attack is a vasomotor disturbance; and there is no evidence that uric acid itself can in fact produce such an effect.

\section{Summary}

Observations are described of seven cases of gout treated with probenecid, urinary uric acid and blood uric acid estimations being carried out at the same time.

Attacks of acute gout were studied; these occurred at a time when the level of circulating urate had been brought to normal.

Attention is drawn to one possible explanation of this phenomenon: that not uric acid per se but a precursor may be responsible for the acute paroxysm. The use of a uricosuric agent, such as probenecid, has enabled quantitative studies to be made, which provide some evidence that uric acid in the solid phase is in equilibrium with uric acid in body fluids.

With the exception of Case 6 , all the patients were under the care of Dr. W. S. C. Copeman, to whom I am greatly indebted, both for permission to study his cases and for his helpful advice.

I am also grateful to Dr. H. E. Archer, Dr. F. Kellett, Dr. H. Loewenthal, and Dr. J. D. Robertson for their 
advice on the biochemical investigations, to $\mathrm{Mr}$. W. D. Coltart for carrying out the tophectomy in Case 2, and to Miss Gee and Mr. R. Smith for many of the estimations.

\section{REFERENCES}

Barnett, A. J. (1951). Brit. med. J., 1, 734

Bauer, W. (1943). New Engl. J. Med., 229, 583.

- - and Klemperer, F. (1947). In "Diseases of Metabolism", 2nd ed., p. 611 (or chap. 12), ed. G. G. Duncan. Saunders, Philadelphia.

Benedict, J. D., Forsham, P. H., Roche, M., Soloway, S., and Stetten, DeWitt (1950). J. clin. Invest., 29, 1104.

- - and Stetten, DeWitt (1949). J. biol. Chem., 181, 183. Roche, M., Yü, T. F., Bien, E. J., Gutman, A. B., and Stetten, DeWitt (1952). Metabolism, 1,3.

Benedict, S. R., and Franke, E. (1922). J. biol. Chem., 52, 387.

Bidmead, D. S. (1951). J. clin. Path., 4, 370.

Bishop, C., Garner, W., and Talbott, J. H. (1951a). J. clin. Invest., 30, 879 .

- Rand, R., and Talbott, J. H. (1951b). Ibid., 30, 889

Blauch, M. B., and Koch, F. C. (1939). J. biol. Chem., 130, 443.

Block, W. D., and Geib, N. C. (1947). Ibid., 168, 747.

Boger, W. P., Beatty, J. O., Pitts, F. W., and Flippin, H. F. (1950). Ann. intern. Med., 33, 18.

- and Crosson, J. W. (1950). Amer. J. Med., 9, 35.

Brøchner-Mortensen, K. (1937). Acta med. scand., Suppl. 84. (1939). Ibid., 99, 538.

Brown, H. (1945). J. biol. Chem., 158, 601.

Buchanan, O. H., Block, W. D., and Christman, A. A. (1945). Ibid., 157, 181.

Cohen, A. (1936). Amer. J. med. Sci., 192, 488.

Folin, O. (1933). J. biol. Chem., 101, 111.

Folin, O. (1933). J. biol. Chem

(1934). Ibid., 106, 311.

and Trimble, H. (1924). Ibid., 60, 473.

Forsham P. H., Thorn, G. W., Bergner, G. E., and Emerson, K. (1946). Amer. J. Med., i, 105.

(1946) Prunty, F. T. G., and Hills, A. G. (1948). J. clin. Endocr., 8, 15

Garrod, A. B. (1848). Med.-chir. Trans., 31, 83.

Graham, G. (1920). Quart. J. Med., 14, 10.

Gutman, A. B. (1953). Ann. intern. Med., 39, 1052.

-, and Ÿü, T. F. (1950). Amer. J. Med., 9, 24.

(1951). Tran. Ass. Amer. Phys., 64, 279.

Hellman, L. (1949). Science, 109, 280.

Hench, P. S., Vanzant, F. R., and Nomland, R. (1928). Coll. Pap. Mayo Clin., 20, 790.

Hill, L. C. (1938). Lancet, 1, 826.

Jacobson, B. M. (1938). Ann. intern. Med., 11, 1277.

Johnstone, J. M. (1952). J. clin. Path., 5, 317.

Levin, M. H., Rivo, J. B., and Bassett, S. H. (1953). Amer. J. Med.,

Marson, F. G. W. (1953). Quart. J. Med., 22, 331.

Marson, F. G. W. (1953). Quart. J. Med. 22, 331.

Mason, R. M. (1951). Proc. roy. Soc. Med., 44, 289.
Osler, W., and McCrae, T. (1920). "The Principles and Practice of Medicine", 9th ed., p. 414. Appleton, New York and London.

Plimmer, R. H. A. (1918). "Practical Organic and Bio-chemistry", 3rd ed., p. 554. Longmans, Green, London.

Robinson, W. D., Conn, J. W., Block, W. D., and Louis, L. H. (1948). J. Lab. clin. Med., 33, 1473.

Sirota, J. H., Yü, T. F., and Gutman, A. B. (1952a). J. clin. Invest., 31, 692.

-, 31, 6 (1952b). Fed. Proc., 11, No. 1.

Shemin, D., and Rittenberg, D. (1947). J. biol. Chem., 167, 875.
Sydenham, T. (1685). “Opera universa.” Kettelby, London. "The Whole Works of that Excellent Practical Physician, Dr. Thomas Sydenham", translated by John Pechey, 1696; 8th ed., 1722. London.

Talbott, J. H. (1940). J. clin. Invest., 19, 645.

(1951). Proc. Inst. Med. Chicago, 18, 383.

Bishop, C., Norcross, B. M., and Lockie, L. M. (1951). Trans. Ass. Amer. Phys., 64, 372.

- , and Coombs, F. S. (1938a). J. clin. Invest., 17, 508. (1938b). J. Amer. med. Ass., 110, 1977.

, Jacobson, B. M., and Oberg, S. A. (1935). Ibid., 14, 411.

Thorn, G. W., Forsham, P. H., Frawley, T. F., Hill, S. R., Roche, M., Staehelin, D., and Wilson, D. L. (1950). New Engl. J. Med., 242, 824 .

Wolfson, W. Q., Cohn, C., Levine, R., and Huddlestun, B. (1948). Amer. J. Med., 4, 774.

- Hunt, H. D., Cohn, C., Robinson, W. D., and Duff, I. F. (1950). J. Mich. med. Soc., 49, 1058,1083

Wollaston, W. H. (1797). Philos. Trans., 87, 386

Wood-Jones, F. (1948). Lancet, 1, 165.

(1950). Brit. med. J., 1, 561.

Yü, T. F., and Gutman, A. B. (1951). Amer. J. Med., 11, 765.

Etude de l'effet de Probenecid ('Benemid') sur la goutte RÉSUMÉ

On présente les observations de sept cas de goutte traités par probenecid; au cours du traitement on determinait le taux de l'acide urique dans le sang et dans l'urine.

On étudia les attaques de goutte aiguë; ceux-ci survenaient alors que le taux de l'urate sanguin était ramené à la normale.

On attire l'attention sur une explication possible de ce phénomène: ce n'est pas l'acide urique lui-même, mais un précurseur qui serait responsable des paroxysmes aigus. L'emploi d'un agent uricosurique, tel que probenecid, a permis des études quantitatives indiquant que l'acide urique à sa phase solide se trouve en équilibre avec l'acide urique des liquides du corps.

Estudio del efecto de Probenecid ('Benemid') sobre la gota Sumario

Se presentan observaciones de siete casos de gota tratados con probenecid; durante el tratamiento la tasa del ácido úrico en la sangre y en la orina fué determinada.

Se estudiaron ataques de gota aguda; estos ocurrían en los tiempos en que se normalizaba la tasa del urato sanguíneo.

Se llama la atención sobre una explicación posible de este fenómeno: que no el mismo ácido úrico sino un precursor sería responsable de los paroxismos agudos. El empleo de un agente uricosúrico, como probenecid, hizo posibles los estudios cantitativos indicando que el ácido úrico en su fase sólida está en equilibrio con el ácido úrico de los líquidos del cuerpo. 